\title{
Crossing the divide: promoting confidence in contact in a diverse world
}

\author{
Rhiannon N. Turner
}

Joint British Academy/British Psychological Society Lecture, read 12 September 2019.

Abstract: We are living in an increasingly diverse world, an exciting prospect given that positive interactions between people from different social groups have numerous benefits. Unfortunately, however, people often fail to engage in such interactions. Moreover, there is evidence that prejudice, both at an individual and a societal level, remains prevalent. To navigate the diverse world in which we live and, in turn, promote positive intergroup relations, it is important to develop skills and beliefs that will enable us to engage confidently in cross-group relationships. This article will highlight research which demonstrates some of the many benefits of engaging in intergroup contact, from more positive intergroup relations to broader changes in the way we think. The importance of promoting confidence at engaging in contact and its potential predictors and outcomes will be considered. Finally, interventions-specifically extended contact, imagined contact and online contact or e-contact - will be outlined that can help to make people more confident, and in turn more likely to engage in successful interactions with people from different backgrounds to themselves.

Keywords: Intergroup contact, extended contact, imagined contact, e-contact, intergroup relations.

Note on the author: Rhiannon Turner is Professor of Social Psychology and Director of the Centre for Identity and Intergroup Relations at Queen's University Belfast. Her main research interests are around how interventions based on intergroup contact theory can be used as a tool to change intergroup attitudes and behaviours.

Rhiannon can be contacted on r.turner@qub.ac.uk and you can follow her on twitter @rrhiannon_turner and @QUBciir

(C) The author(s) 2020. This is an open access article licensed under a

Creative Commons Attribution-NonCommercial-NoDerivs 4.0 Unported License 
We live in an incredibly socially diverse world. We personally categorise ourselves in terms of a whole host of different social groupings: for example, in terms of our ethnicity, our nationality, our sexual orientation, our age and our mental health status. By definition, if we categorise ourselves according to these groups, this means that there are a whole host of groups out there to which we do not belong. Although figures differ depending on source and method of calculation, it is estimated that in the UK around 4.3 million people belong to an ethnic minority (Census 2011), 765,000 people identify as gay, lesbian or bisexual (Integrated Household Survey 2012), nine million people were born overseas, twelve million people are over the age of 65 (Office for National Statistics 2018), and every week, approximately one in six adults experiences a common mental health problem such as anxiety or depression (Mental Health Foundation 2016). And of course, there are a whole host of other ways in which we differ from those around us, including gender, political beliefs, neurotypical or neurodivergent status and so on. Experiencing difference and diversity is then, for most of us, an everyday experience. However, there is evidence that, even when people have the opportunities to engage in intergroup contact, we do not always take up these opportunities, choosing instead to self-segregate (e.g., Al Ramiah et al. 2014). Moreover, despite the opportunities for contact that exist, minority groups continue to experience high levels of prejudice and discrimination (e.g., The Guardian 2018), and are negatively affected by deeply ingrained systematic inequalities (to give just one example, ethnic minority academics earn significantly less than white academics (BBC News 2018)).

Understanding and promoting more positive intergroup relations is an area of interest to academics in numerous domains, including-but not limited toanthropology, education, history, geography, law, political science, psychology and sociology. This is a reflection of the myriad of factors that influence intergroup relations, from historical context, to the influence of power, status and politics. Here, we focus particularly on the contribution that can be made by social psychology, which studies how people's thoughts, feelings and behaviours are influenced by the presence of others. Social psychologists have argued that, if we are to truly succeed in and navigate our diverse social world, we must be able to successfully interact with people from a whole range of different backgrounds. If we are able to have positive, comfortable interactions with people from other social groups, evidence suggests that this will have a range of benefits, from greater societal harmony (Allport 1954, Pettigrew \& Tropp 2006), to changes in the way we perceive ourselves and the world around us (Hodson et al. 2018, Meleady et al. 2019). Moreover, successful contact may play an important role in ensuring majority and minority groups can come together to fight for a more equal society (Becker et al. 2013, Hughes \& Loader 2015). In order to achieve this, we require the necessary confidence, skills, beliefs and experience for successful intergroup interactions (Turner \& Cameron 2016). 
This article will outline some of the benefits of engaging in intergroup contact from a social psychological perspective, before considering why, despite these benefits, we sometimes fail to engage in contact. The concept of 'confidence in contact' will then be introduced, alongside recent initial research into its potential predictors and consequences. Finally, 'indirect contact' interventions that might help to promote confidence at engaging in intergroup contact will be outlined, and directions for future research discussed.

\section{INTERGROUP CONTACT}

The 'contact hypothesis' was proposed in 1954 by Gordon W. Allport. In his influential book, The Nature of Prejudice, Allport made the simple argument that contact between people from different groups would promote more positive relations between those groups. Notably, however, he recognised that contact in and of itself might not always be beneficial. Indeed, race riots and wars between opposing national, ethnic or religious groups might be considered forms of intergroup contact, yet they are clearly not at all beneficial for intergroup relations. Instead, Allport argued that, for intergroup contact to result in more positive perceptions of the other group, it must have certain qualities. In particular, the groups involved must work together cooperatively, should be aiming to achieve common goals, those involved in the contact must be of equal status during the interaction, and there must be institutional support for the contact; for example, schools and workplaces must endorse contact between different social groups.

There have been a huge number of studies on the topic of intergroup contact over the past sixty years, looking at the effects of interactions between a whole host of different groups, including different ethnic groups, religions and nationalities, in countries all over the world. A meta-analysis of over five hundred of these studies spanning over fifty years revealed a robust positive effect of contact in reducing prejudice (Pettigrew \& Tropp 2006). This same research revealed that, in fact, Allport's optimal conditions are not essential for contact to be effective, although they may play an important facilitating role. Many researchers argue that what is perhaps most important is that contact is of high quality and has friendship potential if it is to improve intergroup relations (Brown \& Hewstone 2005, Pettigrew 1997, 1998). Indeed, research suggests that friendship-based contact is an especially effective means of promoting more positive intergroup relations (Davies et al. 2011). Since the publication of Pettigrew and Tropp's meta-analysis, there has been a further resurgence of research on intergroup contact; there are now over a thousand publications on the topic, exploring important and exciting new developments, including when and how contact 
effects generalise from one group to another, how, when and why different types of contact influence intergroup relations, and moving beyond intergroup attitudes to identify the full breadth of outcomes that contact can have.

It is important to note at this point that intergroup contact is not without its limitations. Dixon and colleagues (2005), for example, note that, while effective on an interpersonal level at changing attitudes, contact may fail to reduce societal inequalities that help to drive prejudice (Dixon et al. 2013). Others have pointed to the 'sedative' effect of contact, whereby, when minority group members have contact with majority groups, they are less likely to engage in collective action to enhance the status of their group (e.g., Dixon et al. 2017, Saguy et al. 2009), in part because, in increasing our affiliation with other groups, contact reduces identification with our own group (Wright \& Lubensky 2009). Despite these shortfalls, however, given the weight of evidence, and its extensive application, particularly in classroom settings, intergroup contact is considered by many social psychologists, educators, practitioners and policymakers as a useful tool for changing social perceptions (e.g., Hewstone 2003).

\section{Benefits for intergroup relations}

There is extensive evidence for the benefits of contact for intergroup relations (see Brown \& Hewstone 2005, Pettigrew \& Tropp 2006, Turner et al. 2007a, for reviews). Turner and colleagues (2007b) conducted several cross-sectional studies to investigate cross-ethnic friendship in the context of relations between the South Asian and white communities in the UK. In one study, white primary school children complete a questionnaire regarding their number and closeness of friendships with, and attitude towards, South Asians. It emerged that, the more time participants spent with South Asian friends, the more positive was their attitude they held towards South Asians in general. This relationship was explained by lower levels of intergroup anxiety and greater levels of self-disclosure. Specifically, children with more South Asian friends were less anxious about interacting with South Asian people and were more likely to share personal information about themselves with South Asian children. In turn, lowered anxiety and heightened self-disclosure were each associated with more positive attitudes. Another study was conducted among secondary school students in the UK city of Bradford, which has a history of tension between the South Asian and white communities. Despite a large Asian population (37 per cent compared to a national average of 4.8 per cent), there is relatively high segregation between the two communities, and we were interested in whether cross-ethnic friendship would still be effective in such a context. Half of the participants were from a South Asian ethnic background, attending a school where 98 per cent of students were South Asian, while the remainder were white and attended a school where 96 per cent of 
students were white. Despite the segregated setting, children in both schools with cross-ethnic friends had more positive attitudes towards the other ethnic group, a relationship that was again explained by higher levels of self-disclosure to the other group. These findings were replicated among a larger independent sample of white high school students and a more comprehensive measure of self-disclosure.

In a rather different context, Turner and colleagues (2013a) examined Catholic and Protestant secondary school pupils with a survey conducted in integrated and non-integrated schools in Northern Ireland. Despite the signing of the Good Friday Agreement and the end of overt conflict over twenty years ago, segregation between the communities remains, with over 90 per cent of children attending either predominantly Catholic or Protestant schools, and only 7 per cent attending integrated schools, which are required to have a certain proportion of Catholic and Protestant students in attendance. Unsurprisingly, children in the integrated schools, who had more opportunities for contact than those in the non-integrated schools, had more crossgroup friendship. Across the whole sample, those who had more cross-group friends reported having more positive attitudes towards the other community, a relationship that was explained by greater self-disclosure and higher levels of empathy.

The positive associations with contact extend beyond more positive attitudes towards the other community. In a further study conducted among Catholic and Protestant undergraduate students in Northern Ireland, experiencing positive contact with the other community predicted greater perceived likelihood of dating someone from the other community, and greater perceived appropriateness of marrying someone from the other community (Paterson et al. 2019). These relationships were explained by the perception that family and friends were positively predisposed towards the idea of cross-community relationships. Put simply, positive contact experiences make us believe that there are positive social norms around cross-community relationships. We are strongly influenced by the attitudes of our group, so this may influence our own perceptions of such relationships. These findings were particularly strong for participants who strongly identified with their own community, presumably because these individuals are especially influenced by the perceived attitudes of their fellow group members. The fact that contact can change perceptions of these relationships is important, because Catholic-Protestant romances are largely stigmatised and are relatively rare (Leonard 2009), yet have the potential to improve intergroup relations by transgressing and transforming group boundaries (Paterson et al. 2015).

It is worth noting at this point that a growing body of evidence suggests that contact is more effective at reducing prejudice among individuals with higher levels of prejudice (see Hodson 2011, Hodson et al. 2017, Turner et al. in press, for reviews), and among those with little (Al Ramiah et al. 2013) or negative (Arnadotir et al. 2018) prior contact experience. This is important because it means that contact is a genuinely 
useful intervention rather than 'preaching to the converted'; it really does work among those who stand to benefit the most.

\section{Benefits beyond intergroup relations}

There is also growing evidence that contact can change the way we think about the world, making us more open to new ideas and ways of thinking. This is a process that Hodson and colleagues (2018) refer to as cognitive liberalisation. They point to studies which demonstrate that contact improves attitudes not only toward the group with whom people have had contact but also towards other, uninvolved, groups, a phenomenon known as the secondary transfer effect (e.g., Pettigrew 2009, Tausch et al. 2010). They also note the growing body of evidence which suggests that engaging meaningfully with diversity through contact can enhance our ability to incorporate multiple perspectives, and in turn improve critical thinking, problem solving and creativity (see also Crisp \& Turner 2011, for a review). Furthermore, contact can make people less inward looking and more open to experiences (e.g., Pettigrew 1997, Sparkman et al. 2016, Verkuyten et al. 2010).

One recent study which demonstrates this was conducted by Vezzali et al. (2018), who had 388 majority (Italian) and 109 minority (immigrant) first-year high-school students complete a survey assessing their level of contact with the other group and their scores on a number of personality traits at the start and end of the school year. Quality of contact at the start of the year predicted greater agreeableness, a trait associated with being warm, friendly and getting along well with others, and openness to experience, a trait associated with a preference for variety and learning new things, at the end of the school year. These findings emerged for both majority and minority children. One interpretation of these findings is that, as young people interact with people from different social backgrounds to themselves, they experience changes in both how they perceive themselves (for example, as a kind, inclusive person, who is confident in engaging with diversity) and how they observe themselves being perceived by others (for example, experiencing approval from teachers and peers). In turn, these observations may lead them to perceive themselves as more agreeable and open. These findings are important because, if someone comes to sees themselves as a person who is agreeable and open to experience, they may be more likely to act in accordance with this self-perception, leading to an increased likelihood of seeking out contact experiences, and behaving positively during those experiences, in the future.

There is also evidence that contact reduces ideological views about hierarchy. People vary in the extent to which they hold a social dominance orientation (SDO), a preference for hierarchical social systems where groups perceived as superior dominate over groups considered to be inferior (Pratto et al. 1994). In contrast to people 
low in SDO, who believe that all people should be treated equally, those high in SDO hold higher levels of prejudice towards a range of groups, including ethnic minorities, homosexuals and women (Sidanius et al. 2000). Experiencing contact with other groups, however, increases our preference for societal equality (e.g., Dhont et al. 2014, Shook et al. 2016, Van Laar et al. 2005).

Expanding on these findings, recent research examined whether contact might also affect our attitudes and behaviours around environmental issues. Those high in SDO are more likely to exploit the natural environment (Milfont \& Duckitt 2010, Milfont et al. 2013, Pratto et al. 1994) and less likely to believe that climate change is real (Häkkinen \& Akrami 2014, Hoffarth \& Hodson 2016). This is because environmental exploitation helps to sustain and increase social inequalities through the hierarchical distribution of natural resources, something that those high in SDO are motivated to achieve (Milfont \& Sibley 2014, Stanley et al. 2017). In contrast, those who engage in environmentally responsible behaviours do so not just because they care about the environment, but also because of equality concerns; such behaviours are likely to help ensure the equal distribution of limited natural resources (Douglas \& Wildavsky 1982).

Given that environmental exploitation is congruent with social dominance motives, it follows that strategies such as intergroup contact that attenuate SDO may have implications for environmental attitudes and behaviours. Across four studies, one of them longitudinal, Meleady and colleagues (2019) found that white British participants' experience of contact with international students and ethnic minorities predicted greater environmental concern, more pro-environmental behaviours (e.g., recycling, conservation, consumer and transportation behaviours) and less climate change denial. In each study, the relationship between contact and environmental outcomes was explained by a reduction in the extent to which people held a social dominance orientation.

\section{The problem with contact}

The findings outlined above highlight the varied benefits of intergroup contact in terms of promoting more positive intergroup relations and changing the way we see ourselves, and how we think about the world. Yet, despite its advantages, research evidence suggests that it is not always easy to get people to actually engage in intergroup contact in the first place, even in contexts where there are clear opportunities for contact. Al Ramiah et al. (2014), for example, found that in British schools where there were both white and Asian children, children from these two ethnic groups avoided sitting with one another in the cafeteria outside of classes. In Northern Ireland, McKeown et al. (2016) observed intergroup behaviour through seating 
choices in the classroom at three points across the school year between Catholics and Protestant students attending integrated secondary schools. They found persistent religious segregation over time, despite the potential for intergroup contact. Other research in schools similarly demonstrates that children's friendship groups often do not reflect the ethnic make-up of the school. Cross-race friendships are relatively uncommon (Aboud \& Sankar 2007, McDonald et al. 2013, Wilson et al. 2014), are less durable, and decline with age (Aboud et al. 2003, Graham \& Cohen 1997). Put simply, from a relatively young age, people are choosing to segregate along group lines.

So why is it that people avoid intergroup interactions? Al Ramiah and colleagues (2014) note that some people are simply not interested in interacting with members of other groups. Indeed, there is evidence that a perception of a lack of things in common with people from other groups may drive self-segregation (Verkuyten \& Steenhuis 2005). However, perhaps one of the most commonly investigated reasons for the lack of meaningful interactions is the role played by intergroup anxiety (Stephan \& Stephan, 1985). People may feel anxious because they anticipate the interaction being awkward and uncomfortable, because they worry about inadvertently saying something offensive or discriminatory, they may anticipate being rejected by the outgroup, or a combination of these reasons. Trawalter et al. (2009) argue that, when individuals appraise intergroup interactions as threatening in this way, it can result in feelings of stress. If the perception exists that the demands faced exceed the available resources, a person feels they have to deal with the interaction, and this may result in people avoiding contact with people from other groups altogether. However, even if an interaction does occur, feelings of anxiety may result in inadvertent negative behaviours: for example 'freezing', whereby the individual becomes silent and immobile during interactions, because they are busy trying to cope with their nerves rather than focusing on ensuring a pleasant interaction (e.g., Mendoza-Denton et al. 2006, Plant \& Devine 2003). These kinds of reactions have the potential to make relations between groups worse rather than better. It is therefore imperative that researchers and practitioners find ways to instill confidence around engaging in contact, because if we can make people 'contact ready', this will increase the chances that they have positive crossgroup interactions and, in turn, form high-quality cross-group friendships that are maintained over time.

\section{CONFIDENCE IN CONTACT}

Confidence in contact can be defined as a state of readiness for positive contact whereby people have the skills, beliefs and experience necessary to ensure contact experiences are positive when the opportunity arises, resulting in an increased 
uptake of cross-group friendships (Turner \& Cameron 2016). Confident individuals are expected to hold a specific set of characteristics. They will have positive perceptions of people from other groups, and low levels of anxiety about interacting with and forming friendships with them. They will not feel heightened levels of stress in anticipation of and during intergroup interaction because they anticipate positive, comfortable and friendly interactions. They also may believe that they will personally benefit from engaging in such interactions. They are likely to be those individuals who recognise that they share similarities with outgroup members, and who perceive themselves to be in a supportive social climate in which peers and authority figures accept and encourage cross-group friendships. Those with confidence in contact are also likely to have a range of skills and perspectives that will lead to positive approaches to diversity and effective intergroup interactions, including the ability to emphasise with and take the perspective of outgroup members and good social skills. Taken together, these things should mean that these individuals have high cross-group friendship self-efficacy, the belief that they can successfully befriend people from other backgrounds.

So what factors might promote this self-efficacy, this confidence in contact? Bagci and colleagues (2019) undertook two surveys with Year 7 and Year 8 (aged 11-13 years) secondary school pupils in the UK from a range of ethnic backgrounds. Experience of positive contact with other ethnic groups at primary school, knowing other people from one's own group who had friends in other ethnic groups, having lower levels of anxiety about interacting with people from other ethnic groups, and believing that one's parents had high quality cross-ethnic friendships, each predicted greater confidence in befriending ethnic outgroup members and, in turn, higher quality cross-ethnic friendships. So why did these predictors emerge as being important? Having past positive contact experiences and knowing about the positive contact experiences of our peers and family members, often referred to as 'extended contact' (Wright et al. 1997), provides us with a model of what positive intergroup contact looks like. This promotes self-efficacy which increases our likelihood of engaging in positive intergroup contact ourselves (Bandura 1986). It is important to note that these findings are cross-sectional, so we cannot infer causal direction or be sure what will happen over time. Nonetheless, the initial evidence gives us some important clues as to how we might develop interventions to promote confidence in contact.

\section{PROMOTING CONFIDENCE IN CONTACT VIA INDIRECT CONTACT}

Given that the findings of Bagci and colleagues (2019) highlight the role of a 'positive contact model', it stands to reason that interventions which help to highlight these models might be especially effective at promoting confidence at engaging in contact, 
and in turn promoting more positive behaviour during contact. 'Indirect' contact interventions, approaches which are based on the principles of Allport's (1954) contact hypothesis but do not actually involve a face-to-face encounter with an outgroup member, may be particularly valuable in this regard. Below three types of indirect contact intervention are discussed that help to provide a positive model for subsequent face-to-face contact and in doing so enhance confidence: extended contact, imagined contact, and online contact.

\section{Extended contact}

Extended contact is the premise that knowing people from the ingroup who have friends in an outgroup, or learning about the cross-group friendship experiences of our same-group peers, can promote more positive outgroup attitudes (Wright et al. 1997). It promotes a number of the psychological processes associated with feeling more confident about engaging in contact. It enhances positive perceptions of ingroup and outgroup norms; that is, when we learn about the cross-group friendships of others, we deduce that ingroup and outgroup members are interested in positive relations with one another (Turner et al. 2008, 2013a). By presenting intergroup contact in a positive light, extended contact is associated with more positive expectations about contact, resulting in less intergroup anxiety (Gomez et al. 2011, Turner et al. 2008, 2013a). Moreover, extended contact increases the extent to which we perceive there to be similarity between ourselves and the outgroup (Turner et al. 2008). In sum, it seems that extended contact works by providing people with an example of what successful contact looks like and reminds them of similarities they share with people from other groups, making anxious individuals more confident that they can achieve positive contact themselves. Indeed, there is evidence that extended contact increases self-efficacy about personally engaging in intergroup contact, increases willingness to engage in future contact (Mazziotta et al. 2011), enhances perceptions of how enjoyable future contact would be (Gomez et al. 2011) and increases subsequent numbers of cross-group friends (Wölfer et al. 2018).

West and Turner (2014) examined whether these more positive self-reported perceptions following extended contact would reduce anxiety reactions and translate into more positive, confident behaviour when interacting with a member of a stigmatised group, specifically a person who purportedly had a diagnosis of schizophrenia. Undergraduate students watched a two-minute video showing a male and female student having a friendly interaction. In the extended contact condition, they were told that the male student in the video had schizophrenia, whilst in the control condition they were told that it was just an interaction between two students. After watching the video, participants were told that they themselves were going to engage 
in an interaction with a male student who had schizophrenia. Two minutes later, they were introduced to the student, for a short interaction. In reality, this student was recruited by us to play the role of this supposed individual with schizophrenia. He always behaved in a pleasant, positive way towards their interaction partner, and no mention was made of his condition, but nonetheless participants believed that this person had schizophrenia.

This research design was used to address two key research questions. First, does extended contact make people less anxious about personally interacting with someone who has schizophrenia? Contact with someone from another group is anxiety inducing and has been shown in the past to lead to an increased heart rate and greater sweating, both indicators of stress. However, these stress reactions should be lessened among participants who believed they had observed a positive interaction with someone with schizophrenia and had learnt from this that they had nothing to fear from such an interaction. Second, does extended contact make a subsequent encounter with someone who does have schizophrenia more comfortable and pleasant? That is, because they should feel more confident about engaging in contact, might their body language reflect this, resulting in a more pleasant interaction?

In line with predictions, West and Turner (2014) found that, when participants learnt they would be meeting someone with schizophrenia, they showed an increase in heart rate and sweating, indicating increased stress. However, this increase was significantly smaller among participants who had experienced extended contact. Moreover, among those who had experienced extended contact, more positive non-verbal behaviours such as nodding and smiling were displayed during the subsequent intergroup encounter, and these interactions were rated as more pleasant by the individual posing as someone with schizophrenia. These findings are indicative that extended contact does indeed make people feel more confident about engaging in contact, resulting in a more successful interaction.

So how can extended contact be applied outside of the laboratory? Cameron and colleagues have developed a successful extended contact programme for use in primary schools. Once a week for several weeks, children read illustrated stories portraying intergroup friendships, and then engage in small group discussions about the stories. The intervention has proven successful in a number of contexts; for example, children who read stories featuring friendships between white English children and refugees (Cameron et al. 2006, 2007), non-disabled and disabled children (Cameron \& Rutland 2006) and English and Indian-English children (Cameron et al. 2011a) subsequently held more positive attitudes and greater willingness to play with member of the other group.

Extended contact can also be incorporated into programmes for use with older children. Vezzali and colleagues (2015a) found that teenagers who read books featuring 
positive intercultural contact subsequently reported fewer stereotypes, more positive attitudes and a greater desire for future contact with immigrants. Learning about the positive contact experiences of peers is also a useful strategy. Vezzali et al. (2015b) asked Italian elementary and high school students to work in small groups on a competition to come up with the best essay about friendships with immigrants. In doing so, they exchanged information about their own experiences with immigrants to create a good-quality essay. This resulted in more positive perceptions of how both Italians and immigrants feel about intergroup contact and, in turn, children reported having more friends with an immigrant background three months later. Finally, watching TV shows which feature positive intergroup encounters can also be an effective way of introducing extended contact (see Mares \& Pan 2013, for a review).

\section{Imagined contact}

Another type of intervention which might help to promote confidence in contact is imagined contact. This is the idea that just imagining a positive interaction with someone from another group can change attitudes towards that group (Crisp \& Turner 2009, 2012, Stathi \& Crisp 2008). Imagining what a positive encounter with someone from another group might be like is thought to activate concepts normally associated with successful interactions with members of other groups, such as feeling more comfortable and less apprehensive about contact (Turner et al. 2007a). In addition, when we make detailed plans, as is the case during imagined contact, this provides a behavioural script that can provide a roadmap for future behaviour (Gollwitzer, 1993), potentially making those encounters more positive and comfortable. There are now over a hundred studies on imagined contact showing that it promotes more positive perceptions of ethnic minorities, immigrants, physically disabled individuals, asylum seekers, older adults, higher weight people and individuals with mental health difficulties (see Miles \& Crisp 2014, for a meta-analysis).

Crucially, imagined contact promotes mechanisms associated with confidence in contact, including increasing self-efficacy about contact (Stathi et al. 2011) and reduced intergroup anxiety (Birtel \& Crisp 2012, Turner et al. 2007c). So as with extended contact, we were interested in seeing whether imagined contact might also affect people's behaviour when interacting with members of other groups. We started off with a very simple study, in which undergraduate students were asked to spend two minutes 'imagining yourself meeting someone who is a Muslim for the first time or, in a control condition, to spend two minutes 'imagining yourself meeting a stranger for the first time'. In both cases, participants were asked to imagine that the interaction was relaxed, positive and comfortable. Next, they were told that 
they would be meeting someone who happens to be Muslim for a brief interaction. Participants were taken to an empty room with a stack of chairs in the corner which the experimenter noted that they hadn't got around to preparing. The participant was then asked to get out a couple of chairs for the interaction while the experimenter went to get the Muslim interaction partner. In fact, no interaction took place: the dependent measure was how close the chairs were placed together for the interaction. We found that participants who had previously imagined contact with someone Muslim put the chairs on average $17 \mathrm{~cm}$ closer together than those who had imagined contact with a stranger. This is important because research has shown that, if we increase distance from someone during an interaction, the person we meet will deduce that we don't like them very much, making for a more awkward, and less pleasant encounter (Rosenfeld 1965).

Next, we examined whether imagined contact also affects physiological indicators of anxiety when anticipating intergroup contact and the subsequent success of an intergroup encounter (West et al. 2015). Students spent a minute imagining a positive encounter with an individual with schizophrenia (imagined contact condition) or with a stranger (control condition), before engaging in a brief encounter with an individual whom they believed to have schizophrenia. In line with the findings for extended contact (West \& Turner 2014), we found that participants who had imagined contact showed less of an increase in heart rate and skin reactivity when anticipating an interaction with someone with schizophrenia than participants in the control condition. Moreover, the student posing as someone with schizophrenia rated the interaction as on average more pleasant when they were with a partner who had previously imagined contact. Although we did not include a direct measure of self-efficacy, or other aspects of confidence in contact, these findings are indicative that imagined contact makes people feel more confident about engaging in contact, which may contribute to a more successful subsequent interaction.

An important question is whether this laboratory-based technique can be applied successfully as an intervention. Studies with school children show that it can be an effective approach. Stathi and colleagues (2014), for example, asked white 7-11-year olds to create three weekly stories using pictures about a day spent with an Asian child. Compared to classmates who did not undertake the intervention, children held more positive attitudes, perceived themselves to be more similar, and had greater willingness to engage in future contact with Asian people. Birtel et al. (2019) similarly found that pre-schoolers who imagined and drew a meeting with or wrote a letter to a black or disabled child subsequently reported a greater intention to engage in intergroup contact (see also Cameron et al. 2011b, Turner et al. 2013b, Vezzali et al. 2011). 


\section{Online contact}

A final approach which has the potential to promote confidence in contact is online intergroup contact, or e-contact (Amichai-Hamburger \& McKenna 2006, White \& Abu-Rayya 2012), which involves interacting via chat software with someone from another group. Although online chat-based contact involves personally interacting with someone from another group, it remains distinct from face-to-face contact because of the reduced proximity, lack of visual cues from the interaction partner, and additional time participants have to formulate a response to their interaction partner.

These unique characteristics may be important in helping to promote confidence in contact (Amichai-Hamburger \& McKenna 2006). First, individuals meet the interaction partner while staying within their own familiar physical surroundings, where they feel comfortable. Second, they are not under visual scrutiny, and so any negative non-verbal cues triggered by anxiety during initial interactions are not visible to the interaction partner and are thus less likely to result in negative interpretation which might hinder the interaction. Third, because they don't have to respond instantaneously but instead can take time to formulate a response, they have a higher level of control over how they present themselves and therefore will not only feel more at ease, but also be able to express themselves better. Fourth, people tend to self-disclose, or share personal information about themselves, more during online intergroup encounters than face to-face and, as noted earlier, self-disclosure during intergroup contact is important in promoting empathy, trust and more positive perceptions of other groups (Turner et al. 2007c). It is also noteworthy that, as an intervention, online contact is appealing because it is cheaper and practically easier to instigate than face-to-face contact. White and colleagues (2019) found that Catholic and Protestant undergraduate students in Northern Ireland, who believed they were interacting online with a member of the other community to come up with ideas for a new brochure for freshers on life at university, subsequently reported less anxiety and more positive expectations about contact with the other community compared to participants who believed they had engaged in an online interaction with an ingroup member. These findings suggest that online contact might help to prepare people for face-to-face contact by increasing confidence.

Online contact has been used to promote intergroup contact in the classroom, particularly through blended contact, which involves linking pupils from schools involved in shared education - partnerships between Catholic and Protestant schools where students from the two classes are taught together for some of their classesthrough a combination of face-to-face work and online interaction (Austin \& Hunter 2013, Austin et al. 2007). Austin and Turner (2020) explored teachers' reactions to 
using online contact as part of their shared education classes. After training in use of a virtual learning environment for shared communication, teachers ran a six-week programme incorporating these resources. In a survey following completion of the training, teachers reported that, on introducing blended contact, they had seen the most change in terms of pupils' development of cross-community friendships, noting that 'regular access to each other in online forums has meant that children have a chance to chat in a way which is familiar to them' and 'leaving comments for each other ... and then matching the comment to the person during face-to-face activities helped to build on relationships'. Other comments referred to the 'cementing' or 'reinforcing' of relationships as a result of discovering similar interests through working in a safe online environment.

\section{SUMMARY AND SUGGESTIONS FOR FUTURE RESEARCH}

The research reviewed highlights that past contact experiences, learning about the positive contact experiences of others and reduced anxiety promote greater confidence in contact, which in turn predicts more positive contact (Bagci et al. 2019). This is important given the benefits that intergroup contact can bestow in terms of more positive intergroup relations (Brown \& Hewstone 2005, Paterson et al. 2019, Pettigrew \& Tropp 2006, Turner et al. 2007a, 2007b, 2013a). Moreover, interventions which draw on intergroup contact theory but do not involve (initially, at least) face-to-face encounters with outgroup members can help to reduce stress, bolster confidence in contact and promote more positive intergroup encounters (Turner \& West 2012, West \& Turner 2014, West et al. 2015). But research on confidence in contact is in its relative infancy and there is much work to be done. To date there has not been a comprehensive test of what factors predict confidence in contact, as outlined in Turner and Cameron's (2016) proposed model, and in turn what the outcomes of this are for intergroup relations over time. This type of longitudinal research will be important if we are to develop comprehensive and effective interventions to promote confidence in contact.

We must also consider a broad range of preparatory tools that might help the likelihood that people will seek out contact and then go on to have positive contact experiences, and then figure out how they can be applied. In addition to work on the indirect forms of contact outlined in this paper, which focus on reducing anxiety, another approach is to increase motivation and interest in engaging in intergroup contact. Migacheva and Tropp (2012), for example, found that encouraging people to focus on learning goals rather than performance goals when interacting with outgroup members - that is, getting them to think about what they could learn from the 
interaction rather than how they are performing during it - resulted in greater interest in and comfort about intergroup contact. This may in part be because students are less focused on themselves and how they are coming across, and so are less likely to experience intergroup anxiety. Paolini and colleagues (2016) similarly found that reminding students of the benefits of being open to new challenges, seeking novelty and expanding oneself predicted greater interest in interacting with people from different groups. It is possible that using these various approaches in combination might be especially likely to increase contact seeking, by increasing both confidence and motivation.

The social psychology interventions discussed here are often either undertaken in the laboratory or in the field, but on a relatively small scale. Moreover, they do not always take into account factors that might constrain the effectiveness of such interventions. In Northern Ireland, for example, Catholic and Protestants attending separate schools and living in segregated communities may have limited opportunity to put their new skills into action, even after engaging in interventions that promote confidence in contact. This may lead some scholars to question whether such approaches can result in meaningful societal change. Interdisciplinary research on intergroup contact which considers in more depth broader factors (for example, historical context, institutional inequality and political structures) will therefore be instrumental in better understanding when and how these interventions can be successfully implemented.

As well as considering preparatory tools like extended, imagined and online contact, it is essential that we consider what we can do during intergroup contact to enhance its effectiveness and ensure that people's confidence continues to grow. One potential barrier to this is that people do not like to talk about issues of identity and difference. During contact between Catholic and Protestant pupils in Northern Ireland, for example, issues of group differences are rarely discussed because of a fear of being construed as offensive, intimidating or provocative, with teachers feeling equally uncomfortable in leading these types of conversations (Loader \& Hughes 2017). People in particular are similarly avoidant when it comes to talking about race during intergroup contact. Norton and colleagues (2006), had white college students play a game of 'Guess Who' with either a white or a black interaction partner. In the game, participants had to use characteristics including background colour, gender and race to help narrow down which of a number of characters their interaction partner had chosen. They found that while 93 per cent of participants asked about race to help identify the character when interacting with another white student, only 64 per cent did so when interacting with a black student.

Even if an interaction is pleasant, if we are not able to comfortably discuss our group identities, it suggests that we have some way to go before we are truly confident 
in engaging in contact. There are also negative implications for intergroup relations. There is evidence that disclosing our group memberships and showing respect for the group membership of our interaction partner is important in the development of cross-group friendships and in promoting positive attitudes towards other groups (Davies \& Aron 2016, Davies et al. 2011). Ignoring this important aspect of who we are, leaving this elephant in the room, may mean that we never become truly close to our friends from other groups. In addition, when conversations around group membership are avoided, the institutional, social and political structures that perpetuate inequality and conflict remain intact (Dixon et al. 2013, Hughes \& Loader 2015). In contrast, when group inequalities are acknowledged by a dominant group, contact between groups can actually help to promote collective action to improve the position of minority groups in society (Becker et al. 2013).

This is why developing confidence at engaging in meaningful intergroup contact is so important, through the preparatory methods of the types I have discussed alongside ensuring children discuss issues of group membership regularly throughout their school careers, with the support of teachers who are trained to facilitate those discussions. If this can be achieved, young people will go out into the world feeling truly confident in engaging with diversity, crossing those group divides to make friends from all different backgrounds. In turn, they can really benefit from the many advantages that intergroup contact can bestow on us.

\section{REFERENCES}

Aboud, F. E. \& Sankar, J. (2007), 'Friendship and Identity in a Language-integrated School', International Journal of Behavioral Development, 31(5): 445-53. https://doi.org/10.1177/0165025407081469

Aboud, F., Mendelson, M. \& Purdy, K. (2003), 'Cross-race Peer Relations and Friendship Quality', International Journal of Behavioral Development, 27(2): 165-73.

https://doi.org/10.1080/01650250244000164

Allport, G. W. (1954), The Nature of Prejudice (Reading, MA, Addison-Wesley).

Al Ramiah, A., Hewstone, M., Little, T. D. \& Lang, K. (2013), 'The Influence of Status on the Relationship Between Intergroup Contact, Threat, and Prejudice in the Context of a Nation-building Intervention in Malaysia', Journal of Conflict Resolution, 58: 1202-29. https://doi.org/10.1177/0022002713492634

Al Ramiah, A., Schmid, K., Hewstone, M. \& Floe, C. (2014), 'Why Are All the White (Asian) Kids Sitting Together in the Cafeteria? Resegregation and the Role of Intergroup Attributions and Norms', British Journal of Social Psychology, 54: 100-24. https://doi.org/10.1111/bjso.12064

Amichai-Hamburger, Y. \& McKenna, K. Y. A. (2006), 'The Contact Hypothesis Reconsidered: Interacting via the Internet', Journal of Computer-Mediated Communication, 11: 825-43. https://doi.org/10.1111/j.1083-6101.2006.00037.x

Arnadottir, K., Lolliot, S., Brown, R. \& Hewstone, M. (2018), 'Positive and Negative Contact: Interaction not Asymmetry', European Journal of Social Psychology, 48: 784-800.

https://doi.org/10.1002/ejsp.2365 
Austin, R. \& Hunter, W. (2013), Online Learning and Community Cohesion: Linking Schools (New York and London, Routledge). https://doi.org/10.4324/9780203074381

Austin, R. \& Turner, R. N. (2020), 'The Role of Blended Contact for Community Cohesion: Lessons from Northern Ireland', Technology, Pedagogy, and Education. http://doi.org/10.1080/1475939X.2020.1756906

Austin, R., Rickard A. \& Reilly J. (2017), 'Face-to face Contact in Blended Learning for Intercultural Education: The Role of Teachers', Irish Educational Studies, 36: 323-40. https://doi.org/10.1080/03323315.2017.1327364

Bagci, S. C., Cameron, L., Turner, R. N., Morais, C., Carby, A., Ndhlovu, M. \& Leney, A. (in press), 'Cross-ethnic Friendship Self-efficacy: A New Predictor of Cross-ethnic Friendships among Children', Group Processes and Intergroup Relations.

Bandura, A. (1986), Social Foundations of Thought and Action: A Social Cognitive Theory (Englewood Cliffs, NJ, Prentice-Hall).

BBC News (2018), 'Ethnic Minority Academics Earn Less Than White Colleagues', retrieved from https://www.bbc.co.uk/news/education-46473269

Becker, J. C., Wright, S. C., Lubensky, M. E. \& Zhou, S. (2013), 'Friend or Ally: Whether Cross-group Contact Undermines Collective Action Depends on What Advantaged Group Members Say (or Don't Say)', Personality and Social Psychology Bulletin, 39: 442-55. https://doi.org/10.1177/0146167213477155

Birtel, M. D. \& Crisp, R. J. (2012), “"Treating” Prejudice: An Exposure-therapy Approach to Reducing Negative Reactions Toward Stigmatized Groups', Psychological Science, 23(11): 1379-86. https://doi.org/10.1177/0956797612443838

Birtel, M. D., Di Bernardo, G. A., Stathi, S., Crisp, R. J., Cadamuro, A. \& Vezzali, L. (2019), 'Imagining Contact Reduces Prejudice in Pre-school Children', Social Development, 28(4): 1054-73. https://doi.org/10.1111/sode.12374

Brown, R. \& Hewstone, H. (2005), 'An Integrative Theory of Intergroup Contact', in M. P. Zanna (ed.) Advances in Experimental Social Psychology (San Diego, CA, Academic Press), 37: 255-343.

Cameron, L. \& Rutland, A. (2006), 'Extended Contact Through Story Reading in School: Reducing Children's Prejudice Towards the Disabled', Journal of Social Issues, 62: 469-88. https://doi.org/10.1111/j.1540-4560.2006.00469.x

Cameron, L., Rutland, A., Brown, R. \& Douch, R. (2006), 'Changing Children's Intergroup Attitudes Towards Refugees: Testing Different Models of Extended Contact', Child Development, 77: 1208-19. https://doi.org/10.1111/j.1467-8624.2006.00929.xx

Cameron, L., Rutland, A. \& Brown, R. (2007), 'Promoting Children's Positive Intergroup Attitudes Towards Stigmatized Groups: Extended Contact and Multiple Classification Skills Training, International Journal of Behavioral Development, 31: 454-66. https://doi.org/10.1177/0165025407081474

Cameron, L., Rutland, A., Hossain, R. \& Petley, R (2011a), 'When and Why Does Extended Contact Work? The Role of High Quality Direct Contact and Group Norms in the Development of Positive Ethnic Intergroup Attitudes Amongst Children', Group Processes and Intergroup Relations, 14, 193-206. doi: 10.1177/1368430210390535

Cameron, L., Rutland, A., Turner, R. N., Blake, B., Holman-Nicolas, R. \& Powell, C. (2011b), 'Changing Attitudes With a Little Imagination: Imagined Contact Effects on Young Children's Implicit Attitudes', Anale de Psicologia, 27(3): 708-17.

Census (2011), Office for National Statistics. https://www.ons.gov.uk/census/2011census

Crisp, R. J. \& Turner, R. N. (2009), 'Can Imagined Interactions Produce Positive Perceptions? Reducing Prejudice Through Simulated Social Contact', American Psychologist, 64: 231-40. https://doi.org/10.1037/a0014718 
Crisp, R. J. \& Turner, R. N. (2011), 'Cognitive Adaptation to the Experience of Social and Cultural Diversity', Psychological Bulletin, 137: 242-66. https://doi.org/10.1037/a0021840

Crisp, R. J. \& Turner, R. N. (2012), 'The Imagined Intergroup Contact Hypothesis', in M. P. Zanna \& J. Olson (eds) Advances in Experimental Social Psychology (Burlington, VT, Academic Press), 46: 125-82. https://doi.org/10.1016/B978-0-12-394281-4.00003-9

Davies, K. \& Aron, A. (2016), 'Friendship Development and Intergroup Attitudes: The Role of Interpersonal and Intergroup Friendship Processes', Journal of Social Issues, 72: 489-510. https://doi.org/10.1111/josi.12178

Davies, K., Tropp, L. R., Aron, A., Pettigrew, T. F. \& Wright, S. C. (2011), 'Cross-group Friendships and Intergroup Attitudes: A Meta-analytic Review', Personality and Social Psychology Review, 15: 332-51. https://doi.org/10.1177/1088868311411103

Dhont, K., Van Hiel, A. \& Hewstone, M. (2014), 'Changing the Ideological Roots of Prejudice: Longitudinal Effects of Ethnic Intergroup Contact on Social Dominance Orientation', Group Processes and Intergroup Relations, 17, 27-44. https://doi.org/10.1177/1368430213497064

Dixon, J., Durrheim, K. \& Tredoux, C. (2005), 'Beyond the Optimal Contact Strategy: A Reality Check for the Contact Hypothesis', American Psychologist, 60: 697-711. https://doi.org/10.1037/0003-066X.60.7.697

Dixon, J., Durrheim, K., Kerr, P. \& Thomae, M. (2013), “"What's So Funny 'Bout Peace, Love and Understanding?" Further Reflections on the Limits of Prejudice Reduction as a Model of Social Change', Journal of Social and Political Psychology, 1: 239-52. https://doi.org/10.5964/jspp.v1i1.234

Dixon, J., Durrheim, K. \& Thomae, M. (2017), 'The Principle-Implementation Gap in Attitudes Towards Racial Equality (and How to Close It)', Advances in Political Psychology, 38: 91-126. https://doi.org/10.1111/pops.12393

Douglas, M. \& Wildavsky, A. (1982), Risk and Culture. An Essay on the Selection of Technical and Environmental Dangers (Berkeley, CA, University of California Press).

Gollwitzer, P. M. (1993), 'Goal Achievement: The Role of Intentions', European Review of Social Psychology, 4(1): 141-85. https://doi.org/10.1080/14792779343000059

Gomez, A., Tropp, L. R. \& Fernandez, S. (2011), 'When Extended Contact Opens the Door to Future Contact: Testing the Effects of Extended Contact on Attitudes and Intergroup Expectancies in Majority and Minority Groups', Group Processes and Intergroup Relations, 14: 161-73. https://doi.org/10.1177/1368430210391119

Graham, J. A. \& Cohen, R. (1997), 'Race and Sex as Factors in Children's Sociometric Ratings and Friendship Choices', Social Development, 6(3): 355-72. https://doi.org/10.1111/j.1467-9507.1997.tb00111.x

The Guardian (2018), 'Revealed: The Stark Evidence of Everyday Racial Bias in Britain', retrieved from https://www.theguardian.com/uk-news/2018/dec/02/revealed-the-stark-evidence-of-everyday-racialbias-in-britain

Häkkinen, K. \& Akrami, N. (2014), 'Ideology and Climate Change Denial', Personality and Individual Differences, 70: 62-5. https://doi.org/10.1016/j.paid.2014.06.030

Hewstone, M. (2003), 'Intergroup Contact-Panacea for Prejudice?', The Psychologist, 16: 352-55.

Hodson, G. (2011), 'Do Ideologically Intolerant People Benefit from Intergroup Contact?', Current Directions in Psychological Science, 20: 154-9. https://doi.org/10.1177/0963721411409025

Hodson, G., Turner, R. N. \& Choma, R. (2017), 'The Role of Personality in Intergroup Contact', in L. Vezzali \& S. Stathi (eds) Intergroup Contact Theory: Recent Developments and Future Direction (Abingdon, Routledge), 8-30.

Hodson, G., Meleady, R., Crisp, R. J. \& Earle (2018), 'Intergroup Contact as an Agent of Cognitive Liberalization', Perspectives in Psychological Science, 13(5): 523-48. https://doi.org/10.1177/1745691617752324 
Hoffarth, M. R. \& Hodson, G. (2016), 'Green on the Outside, Red on the Inside: Perceived Environmentalist Threat as a Factor Explaining Political Polarization of Climate Change', Journal of Environmental Psychology, 45, 40-9. https://doi.org/10.1016/j.jenvp.2015.11.002

Hughes, J. \& Loader, R. (2015), "Plugging the Gap": Shared Education and the Promotion of Community Relations Through Schools in Northern Ireland', British Educational Research Journal, 41: 1142-55. https://doi.org/10.1002/berj.3206

Integrated Household Survey (2012), Integrated Household Survey April 2011 to March 2012: Experimental Statistics. https://www.ons.gov.uk/

Leonard, M. (2009), “'It's Better to Stick to Your Own Kind”: Teenagers' Views on Cross-community Marriages in Northern Ireland', Journal of Ethnic and Migration Studies, 35, 97-113. https://doi.org/10.1080/13691830802489242

Loader, R. \& Hughes, J. (2017), 'Joining Together or Pushing Apart? Building Relationships and Exploring Difference Through Shared Education in Northern Ireland', Cambridge Journal of Education, 47: 117-34. https://doi.org/10.1080/0305764X.2015.1125448

Mares, M. L. \& Pan, Z. (2013), 'Effects of Sesame Street: A Meta-analysis of Children's Learning in 15 Countries', Journal of Applied Developmental Psychology, 34: 140-51. https://doi.org/10.1016/j.appdev.2013.01.001

Mazziotta, A., Mummendey, A. \& Wright, S. C. (2011), 'Vicarious Intergroup Contact Effects: Applying Social-cognitive Theory to Intergroup Contact Research', Group Processes and Intergroup Relations, 14: 255-74. https://doi.org/10.1177/1368430210390533

McDonald, K. L., Dashiell-Aje, E., Menzer, M. M., Rubin, K. H., Oh, W. \& Bowker, J. C. (2013), 'Contributions of Racial and Sociobehavioral Homophily to Friendship Stability and Quality Among Same-race and Cross-race Friends', The Journal of Early Adolescence, 33: 897-919. https://doi.org/10.1177/0272431612472259

McKeown, S., Stringer. M. \& Cairns, E. (2016), 'Classroom Segregation: Where Do Students Sit and How is This Related to Group Relations', British Educational Research Journal, 42: 40-55. https://doi.org/10.1002/berj.3200

Meleady, R., Crisp, R. J., Dhont, K., Hopthrow, T. \& Turner, R. N. (2019), 'Intergroup Contact, Social Dominance and Environmental Concern: A Test of the Cognitive-liberalization Hypothesis', Journal of Personality and Social Psychology. https://doi.org/10.1037/pspi0000196

Mendoza-Denton, R., Page-Gould, E. \& Pietrzak, J. (2006), 'Mechanisms for Coping with Status-based Rejection Expectations', in S. Levin \& C. Van Laar (eds) Stigma and Group Inequality: Social Psychological Perspectives (London, Taylor and Francis), 151-70.

Mental Health Foundation (2016), Fundamental Facts about Mental Health 2016 (London, Mental Health Foundation).

Migacheva, K. \& Tropp, L. R. (2012), 'Learning Orientation as a Predictor of Positive Intergroup Contact', Group Processes and Intergroup Relations, 16: 426-44. https://doi.org/10.1177/1368430212455854

Miles, E. \& Crisp, R. J. (2014), 'A Meta-analytic Test of the Imagined Contact Hypothesis', Group Processes and Intergroup Relations, 17: 3-26. https://doi.org/10.1177/1368430213510573

Milfont, T. L. \& Duckitt, J. (2010), 'The Environmental Attitudes Inventory: A Valid and Reliable Measure to Assess the Structure of Environmental Attitudes', Journal of Environmental Psychology, 30(1): 80-94. https://doi.org/10.1016/j.jenvp.2009.09.001

Milfont, T. L. \& Sibley, C. G. (2014), 'The Hierarchy Enforcement Hypothesis of Environmental Exploitation: A Social Dominance Perspective', Journal of Experimental Social Psychology, 55: 188-93. https://doi.org/10.1016/j.jesp.2014.07.006

Milfont, T. L., Richter, I., Sibley, C. G., Wilson, M. S. \& Fischer, R. (2013), 'Environmental Consequences of the Desire to Dominate and be Superior', Personality and Social Psychological Bulletin, 39: 1127-38. https://doi.org/10.1177/0146167213490805 
Norton, M. I., Sommers, S. R., Apfelbaum, E. P., Pura, N. \& Ariely, D. (2006), 'Color Blindness and Interracial Interaction: Playing the Political Correctness Game', Psychological Science, 17(11): 925-9. https://doi.org/10.1111/j.1467-9280.2006.01810.x

Office for National Statistics (2018), Population of the UK by Country of Birth and Nationality: 2017, 24 May.

Paolini, S., Wright S. C., Dys-Steenbergen, O. \& Favara, I. (2016), 'Self-expansion and Intergroup Contact: Expectancies and Motives to Self-expand Lead to Greater Interest in Outgroup Contact and More Positive Intergroup Relations', Journal of Social Issues, 72: 450-71. https://doi.org/10.1111/josi.12176

Paterson, J., Turner, R. N. \& Conner, M. (2015), 'Extended Contact With Cross-group Romantic Relationships', Journal of Applied Social Psychology, 45: 489-97. https://doi.org/10.1111/jasp.12314

Paterson, J., Turner, R. N. \& Hodson, G. (2019), 'Receptivity to Dating and Marriage Across the Religious Divide in Northern Ireland: The Role of Intergroup Contact', Journal of Applied Social Psychology, 49: 575-84. https://doi.org/10.1111/jasp.12617

Pettigrew, T. F. (1997), 'Generalized Intergroup Contact Effects on Prejudice', Personality and Social Psychology Bulletin, 23(2): 173-85. https://doi.org/10.1177/0146167297232006

Pettigrew, T. F. (1998), 'Intergroup Contact Theory', Annual Review of Psychology, 49: 65-85. https://doi.org/10.1146/annurev.psych.49.1.65

Pettigrew, T. F. (2009), 'Secondary Transfer Effect of Contact: Do Intergroup Contact Effects Spread to Noncontacted Outgroups?', Social Psychology, 40: 55-65.

https://doi.org/10.1027/1864-9335.40.2.55

Pettigrew, T. F. \& Tropp, L. R. (2006), 'A Meta-analytic Test of Intergroup Contact Theory', Journal of Personality and Social Psychology, 90: 751-83. https://doi.org/10.1037/0022-3514.90.5.751

Plant, E. A. \& Devine, P. G. (2003), 'The Antecedents and Implications of Interracial Anxiety', Personality and Social Psychology Bulletin, 29(6): 790-801. https://doi.org/10.1177/0146167203029006011

Pratto, F., Sidanius, J., Stallworth, L. M. \& Malle, B. F. (1994), 'Social Dominance Orientation: A Personality Variable Predicting Social and Political Attitudes', Journal of Personality and Social Psychology, 67: 741-63. https://doi.org/10.1037/0022-3514.67.4.741

Rosenfeld, H. M. (1965), 'Effect of an Approval-seeking Induction on Interpersonal Proximity', Psychological Reports, 17: 120-2. https://doi.org/10.2466/pr0.1965.17.1.120

Saguy, T., Tausch, N., Dovidio, J. F. \& Pratto, F. (2009), 'The Irony of Harmony: Intergroup Contact Can Produce False Expectations for Equality’, Psychological Science, 20: 114-21. https://doi.org/10.1111/j.1467-9280.2008.02261.x

Shook, N. J., Hopkins, P. D. \& Koech, J. M. (2016), 'The Effect of Intergroup Contact on Secondary Group Attitudes and Social Dominance Orientation', Group Processes and Intergroup Relations, 19: 328-42. https://doi.org/10.1177/1368430215572266

Sidanius, J., Levin, S., Liu, J. \& Pratto, F. (2000), 'Social Dominance Orientation, Anti-egalitarianism, and the Political Psychology of Gender: An Extension and Cross-cultural Replication', European Journal of Social Psychology, 30(1): 41-67. https://doi.org/10.2307/3791836

Sparkman, D. J., Eidelman, S. \& Blanchar, J. C. (2016), 'Multicultural Experiences Reduce Prejudice Through Personality Shifts in Openness to Experience', European Journal of Social Psychology, 46: 840-53. https://doi.org/10.1002/ejsp.2189

Stanley, K. S., Wilson, M. S., Sibley, C. G. \& Milfont, T. L. (2017), 'Dimensions of Social Dominance and Their Associations With Environmentalism', Personality and Individual Differences, 107: 228-36. https://doi.org/10.1016/j.paid.2016.11.051

Stathi, S. \& Crisp, R. J. (2008), 'Imagining Intergroup Contact Promotes Projection to Outgroups', Journal of Experimental Social Psychology, 44(4): 943-57. https://doi.org/10.1016/j.jesp.2008.02.003 
Stathi, S., Crisp, R. J. \& Hogg, M. A. (2011), 'Imagining Intergroup Contact Enables Member-to-group Generalization', Group Dynamics: Theory, Research, and Practice, 15(3): 275-84. https://doi.org/10.1037/a0023752

Stathi, S., Cameron, L., Hartley, B. \& Bradford, S. (2014), 'Imagined Contact as a Prejudice-reduction Intervention in Schools: The Underlying Role of Similarity and Attitudes', Journal of Applied Social Psychology, 44: 536-46. https://doi.org/10.1111/jasp.12245

Stephan, W. G. \& Stephan, C. W. (1985), 'Intergroup Anxiety', Journal of Social Issues, 41: 157-75. https://doi.org/10.1111/j.1540-4560.1985.tb01134.x

Tausch, N., Hewstone, M., Kenworthy, J. B., Psaltis, C., Schmid, K., Popan, J., Cairns, E. \& Hughes, J. (2010), 'Secondary Transfer Effects of Intergroup Contact: Alternative Accounts and Underlying Processes', Journal of Personality and Social Psychology, 99: 282-302. https://doi.org/10.1037/a0018553

Trawalter, S., Richeson, J. A. \& Shelton, J. N. (2009), 'Predicting Behavior During Interracial Interactions: A Stress and Coping Approach', Personality and Social Psychology Review, 13: 243-68. https://doi.org/10.1177/1088868309345850

Turner, R. N. \& Cameron, L. (2016), 'Confidence in Contact: A New Perspective on Promoting Crossgroup Friendship Among Children and Adolescents', Social Issues and Policy Review, 10: 212-46. https://doi.org/10.1111/sipr.12023

Turner, R. N., \& West, K. (2012), 'Behavioural Consequences of Imagining Intergroup Contact With Stigmatized Outgroups', Group Processes and Intergroup Relations, 15: 193-202. https://doi.org/10.1177/1368430211418699

Turner, R. N., Hewstone, M., Voci, A., Paolini, S. \& Christ, O. (2007a), 'Reducing Prejudice via Direct and Extended Cross-group Friendship', European Review of Social Psychology, 18: 212-55. https://doi.org/10.1080/10463280701680297

Turner, R. N., Hewstone, M. \& Voci, A. (2007b), 'Reducing Explicit and Implicit Prejudice via Direct and Extended Contact: The Mediating Role of Self-disclosure and Intergroup Anxiety', Journal of Personality and Social Psychology, 9: 369-88. https://doi.org/10.1037/0022-3514.93.3.369

Turner, R. N., Crisp, R. J. \& Lambert, E. (2007c), 'Imagining Intergroup Contact Can Improve Intergroup Attitudes', Group Processes and Intergroup Relations, 10: 427-41. https://doi.org/10.1177/1368430207081533

Turner, R. N., Hewstone, M., Voci, A. \& Vonofakou, C. (2008), 'A Test of the Extended Intergroup Contact Hypothesis: The Mediating Role of Intergroup Anxiety, Perceived Ingroup and Outgroup Norms, and Inclusion of the Outgroup in the Self', Journal of Personality and Social Psychology, 95: 843-60. https://doi.org/10.1037/a0011434

Turner, R. N., Tam, T., Hewstone, M., Kenworthy, J. \& Cairns, E. (2013a), 'Contact Between Catholic and Protestant Schoolchildren in Northern Ireland', Journal of Applied Social Psychology, 43: 216-28. https://doi.org/10.1111/jasp.12018

Turner, R. N., West, K. \& Christie, Z. (2013b), 'Outgroup Trust, Intergroup Anxiety, and Outgroup Attitude as Mediators of the Effect of Imagined Intergroup Contact on Intergroup Behavioural Tendencies', Journal of Applied Social Psychology, 43: 196-205. https://doi.org/10.1111/jasp.12019

Turner, R. N., Hodson, G. \& Dhont, K. (in press), 'Future Directions in the Interplay Between Intergroup Contact and Individual Differences', Personality and Social Psychology Compass.

Van Laar, C., Levin, S., Sinclair, S. \& Sidanius, J. (2005), 'The Effect of University Roommate Contact on Ethnic Attitudes and Behaviors', Journal of Experimental Social Psychology, 41: 329-45. https://doi.org/10.1016/j.jesp.2004.08.002

Verkuyten, M. \& Steenhuis, A. (2005), 'Preadolescents' Understanding and Reasoning About Asylum Seeker Peers and Friendships', Journal of Applied Developmental Psychology, 26(6): 660-79. https://doi.org/10.1016/j.appdev.2005.08.002 
Verkuyten, M., Thijis, J. \& Bekhuis, H. (2010), 'Intergroup Contact and Ingroup Reappraisal: Examining the Deprovincialization Thesis', Social Psychology Quarterly, 73: 398-416. https://doi.org/10.1177/0190272510389015

Vezzali, L., Capozza, D., Giovannini, D. \& Stathi, S. (2011), 'Improving Implicit and Explicit Intergroup Attitudes Using Imagined Contact: An Experimental Intervention With Elementary School Children', Group Processes and Intergroup Relations, 15: 203-12. https://doi.org/10.1177/1368430211424920

Vezzali, L., Stathi, S., Giovannini, D., Capozza, D. \& Trifiletti, E. (2015a), 'The Greatest Magic of Harry Potter: Reducing Prejudice', Journal of Applied Social Psychology, 45: 105-21. https://doi.org/10.1111/jasp.12279

Vezzali, L., Stathi, S., Giovannini, D., Capozza, D. \& Visintin, E. P. (2015b), 'And the Best Essay Is ... Extended Contact and Cross-group Friendship at School', British Journal of Social Psychology, 54: 601-15. https://doi.org/10.1111/bjso.12110

Vezzali, L, Turner, R. N., Capozza, D. \& Trifilleti, E. (2018), 'Does Intergroup Contact Predict Personality? A Longitudinal Study on the Bidirectional Relationship Between Intergroup Contact and Personality Traits', European Journal of Social Psychology, 48: 159-173. https://doi.org/10.1002/ejsp.2313

West, K. \& Turner, R. N. (2014), 'Using Extended Contact to Improve Physiological Responses and Behavior Toward People With Schizophrenia', Journal of Experimental Social Psychology, 50: 57-64. https://doi.org/10.1016/j.jesp.2013.06.009

West, K., Turner, R. N. \& Levita, L. (2015), 'Applying Imagined Contact to Improve Physiological Responses in Anticipation of Intergroup Interactions and the Perceived Quality of These Interactions', Journal of Applied Social Psychology, 45(6): 425-36. https://doi.org/10.1111/jasp.12309

White, F. A. \& Abu-Rayya, H. M. (2012), 'A Dual Identity-Electronic Contact (DIEC) Experiment Promoting Short- and Long-term Intergroup Harmony', Journal of Experimental Social Psychology, 48(3): 597-608. https://doi.org/10.1016/j.jesp.2012.01.007

White, F. A., Turner, R. N., Verrelli, S., Harvey, L. J. \& Hanna, J. R. (2019), 'Improving Intergroup Relations Between Catholics and Protestants in Northern Ireland via E-contact', European Journal of Social Psychology. https://doi.org/10.1002/ejsp.2515

Wilson, T. M., Rodkin, P. C. \& Ryan, A. M. (2014), 'The Company They Keep and Avoid: Social Goal Orientation as a Predictor of Children's Ethnic Segregation', Developmental Psychology, 50(4): 1116-24. https://doi.org/10.1037/a0035040

Wölfer, R., Christ, O., Schmid, K., Tausch, N., Buchallik, F. M., Vertovec, S. \& Hewstone, M. (2018), 'Indirect Contact Predicts Direct Contact: Longitudinal Evidence and the Mediating Role of Intergroup Anxiety', Journal of Personality and Social Psychology, 116: 277-95. https://doi.org/10.1037/pspi0000146

Wright, S. C. \& Lubensky, M. E. (2009), 'The Struggle for Social Equality: Collective Action Versus Prejudice Reduction', in S. Demoulin, J.-P. Leyens \& J. F. Dovidio (eds) Intergroup Misunderstandings: Impact of Divergent Social Realities (New York, Psychology Press), 219-310.

Wright, S. C., Aron, A., McLaughlin-Volpe, T. \& Ropp, S. A. (1997), 'The Extended Contact Effect: Knowledge of Cross-group Friendships and Prejudice', Journal of Personality and Social Psychology, 73(1): 73-90. https://doi.org/10.1037/0022-3514.73.1.73 
Acknowledgements: I would like to gratefully acknowledge the contribution made by Dr Lindsey Cameron to this article. Many of the ideas discussed in the article were developed collaboratively with Dr Cameron and others were inspired by her outstanding applied research on the benefits of indirect contact interventions among children.

To cite the article: Rhiannon N. Turner (2020), 'Crossing the divide: promoting confidence in contact in a diverse world', Journal of the British Academy, 8: 51-74. DOI https://doi.org/10.5871/jba/008.051

Journal of the British Academy (ISSN 2052-7217) is published by

The British Academy, 10-11 Carlton House Terrace, London, SW1Y 5AH

www.thebritishacademy.ac.uk 